\title{
Clinical Uses of Lactate and Lactate Clearance in Carbon Monoxide Poisoning
}

\author{
Karbon Monoksit Zehirlenmesinde Laktat ve Laktat Klirensinin Klinik Kullanımı
}

\author{
(D) Seda Dağar, (D) Emine Emektar, (D) Hüseyin Uzunosmanoğlu, (D) Şeref Kerem Çorbacıoğlu, (D) Özge Öztekin, (D) Yunsur Çevik
}

Ankara Keçiören Training and Research Hospital, Clinic of Emergency Medicine, Ankara, Turkey

\begin{abstract}
Introduction: This study aimed to investigate lactate and lactate clearance and to determine the feasibility of the use of lactate clearance for assessing treatment efficacy in carbon monoxide (CO) poisoning.

Methods: All patients aged 18 years and older with CO intoxication between 01.06.2016 and 28.02.2018 were included. $\mathrm{COHb}$ levels, initial (lactate-1), and post-treatment control lactate (lactate-2) levels, lactate clearance, type of treatment [normobaric, or hyperbaric oxygen therapy (HBOT)] were recorded. The receiver operating characteristic curve was configured to establish a cut-off point of initial lactate level with the calculated area under the curve (AUC) to predict the need for HBOT.

Results: A total of 103 patients were included. There was a moderate correlation between $\mathrm{COHb}$ and lactate- 1 ( $r=0.49$; $\mathrm{p}<0.001)$ and a weak correlation between $\mathrm{COHb}$ and lactate clearance $(r=0.291 ; p=0.003)$. A significantly higher increase was observed in lactate clearance in the HBOT group ( $p=0.017$ ). The AUC value of initial lactate in predicting the need for HBOT was 0.708 .

Conclusion: The initial lactate level and lactate clearance are rapidly performed and effective markers that may be used in CO intoxication. Especially lactate clearance may provide valuable information in predicting the need for HBOT and assessing treatment efficacy as a monitorization marker.
\end{abstract}

Keywords: Lactate, lactate clearance, carbon monoxide poisoning, emergency department öz

Amaç: Çalışmamızda karbonmonoksit (CO) zehirlenmesinde laktat ve laktat klirensi düzeylerinin araştırılması ve laktat klirensinin tedavi etkinliğini değerlendirmede kullanılabilirliğinin belirlenmesi amaçlanmıştır.

Yöntemler: 01.06.2016-28.02.2018 tarihleri arasında acil serviste CO zehirlenmesi tanısı alan 18 yaș ve üzeri tüm hastalar çalışmaya dahil edildi. $\mathrm{COHb}$ düzeyi, başvuru (laktat-1) ve tedavi sonrası laktat (laktat-2) değerleri, laktat klirensi, uygulanan tedavi türü [gereksinime göre normobarik veya hiperbarik oksijen tedavisi (HBOT)] kaydedildi. Receiver Operating Characteristic (ROC) eğrisi çizilerek HBOT ihtiyacını öngörmek için başvuru laktatın eșik değeri ve eğri altında kalan alan (AUC) hesaplandı.

Bulgular: Toplam 103 hasta çalıșmaya dahil edildi. $\mathrm{COHb}$ ve laktat-1 arasında orta düzeyde korelasyon $(r=0,49 ; p<0,001)$ varken; $\mathrm{COHb}$ ve laktat klirensi arasında ise zayıf bir korelasyon $(r=0,291 ; p=0,003)$ saptandı. HBOT alan grupta laktat klirensi istatistiksel olarak anlamlı düzeyde daha yüksekti $(p=0,017)$. HBOT ihtiyacını öngörmede bașvuru laktat düzeyinin AUC değeri 0,78 olarak saptandı.

Sonuç: Başvuru laktat düzeyi ve laktat klirensi CO zehirlenmesinde kullanılabilecek hızlı ve etkin belirteçlerdir. Özellikle laktat klirensinin, HBOT ihtiyacını öngörmede ve tedavi etkinliğinin değerlendirilmesinde bir izlem parametresi olarak klinisyene faydalı bilgiler sunabileceğini düşünmekteyiz.

Anahtar Kelimeler: Laktat, laktat klirensi, karbon monoksit zehirlenmesi, acil servis

\section{Introduction}

Carbon monoxide ( $\mathrm{CO}$ ) intoxication is one of the most common causes of intoxication-related deaths $(1,2)$. The tissue hypoxia-ischemia combination that the formation of the carboxyhemoglobin $(\mathrm{COHb})$ molecule with higher oxygen affinity creates, is the most important mechanism in the pathophysiology of CO intoxication (3). Although
CO intoxication is diagnosed on the basis of a history of exposure and elevated serum $\mathrm{COHb}$ level, it has been reported that the measured $\mathrm{COHb}$ level is an inadequate predictor of disease severity and prognosis $(4,5)$.

Lactate is a biomarker known to reflect tissue hypoxia, which has been related to prognosis in many disorders. Lactate clearance reflects the rate of lactate removal from the blood (6). The efficacy of lactate clearance 
for treatment guidance in sepsis has led to the performance of studies to evaluate the feasibility of its use in critically ill patients with systemic involvement due to other diseases $(7,8)$. Although several studies reporting a correlation between initial lactate levels and disease severity in $\mathrm{CO}$ exposure have been recently published, there are a limited number of studies examining lactate clearance in CO intoxication (9-12).

In our study, it was aimed to investigate lactate and lactate clearance levels and to determine the feasibility of the use of lactate clearance for assessing treatment efficacy in $\mathrm{CO}$ poisoning.

\section{Methods}

\section{Study Design and Setting}

Our study was conducted in an emergency department where 250.000 patients are admitted annually. A local ethics committee approval (Ankara Keçiören Training and Research Hospital Ethics Committee, decision no: 2012-KAEK-15/1674, date: 23.05.2018) was obtained before the study onset. All patients aged 18 years and older who were diagnosed with CO intoxication in the emergency department between the dates of 01.06.2016 and 28.02.2018 were included. All patient data were obtained by retrospectively scanning hospital records and patients' files. The $\mathrm{COHb}$ level measured from peripheral venous blood gas sample was above $10 \%$ in smokers and above $5 \%$ in non-smokers among patients reporting $\mathrm{CO}$ exposure was accepted as $\mathrm{CO}$ intoxication. Patients with missing data, oncological or hematological disorders, chronic inflammatory disorders (rheumatoid arthritis, vasculitis), and pregnant subjects were excluded. Demographic data, Glasgow Coma scale (GCS) scores, initial COHb levels, initial (lactate-1) and post-treatment control lactate (lactate-2) levels, lactate clearance [lactate clearance $=($ lactate-2)-(lactate-1)], type of administered treatment [normobaric (NBOT) or hyperbaric oxygen therapy (HBOT), depending on the need] were recorded. The lactate-1 level was determined as the lactate level in the first blood gas following emergency department admission. In the patients administered only NBOT, the lactate-2 level was considered as the lactate level measured 4 hours after treatment initiation in the emergency department. When the patient was referred from the emergency department for HBOT, the lactate-2 level was recorded as the lactate level in the first-ever blood gas examination taken after the hyperbaric oxygen session. Venous blood samples obtained from patients with suspected CO intoxication were taken with heparin-containing injectors and studied with the Gestat 1825 (Japan) device. Patients with syncope, loss of consciousness, seizures, coma, focal neurological deficits, and signs of acute myocardial ischemia, or a blood $\mathrm{COHb}$ level $>25 \%$ were referred to HBOT. Other patients were administered $\% 100$ NBOT with a reservoir mask.

\section{Statistical Analysis}

Study data were analyzed with IBM SPSS 20.0 (Chicago, IL, USA) statistical software package. The normality of distribution for discrete and continuous variables was tested using the Kolmogorov-Smirnov test. As the continuous variables did not have a normal distribution, they were expressed as median, minimum, and maximum, while the categorical ones were displayed as number and percentage (\%). Categorical variables were compared using the chi-square test and continuous variables with the Mann-Whitney $U$ test. Correlation analysis between continuous variables was done with Spearman's correlation test. Receiver operating characteristic (ROC) curves were configured to establish cut-off point of plasma lactate level with the calculated area under the curve (AUC) and $95 \%$ confidence interval. A p-value $<0.05$ was considered significant.

\section{Results}

A total of 131 patients were diagnosed with CO intoxication during the study period. Twenty-eight patients were excluded due to missing data, and so a total of 103 patients with CO intoxication were included in the study for statistical analyses. Sixty-eight percent of the study population was female. The most common presenting symptom was headache (78\%). Demographic data and laboratory results were presented in Table 1.

An analysis of the correlation coefficients and their significance between $\mathrm{COHb}$ levels and initial lactate levels and lactate clearance revealed a significant, moderate correlation between $\mathrm{COHb}$ and lactate- 1 ( $r=0.49$; $p<0.001)$. There was a statistically significant and weak correlation between $\mathrm{COHb}$ and lactate clearance $(r=0.291 ; \mathrm{p}=0.003)$ (Table 2).

Nineteen (17\%) patients received HBOT. Those patients had a significantly higher median initial lactate level compared to the NBOT group $(p=0.006)$. A significantly higher increase was observed in the lactate clearance in the HBOT group $(p=0.017)$. An analysis of percentage changes of the lactate levels after the therapy revealed that the drop in

Table 1. The demographic characteristics of the patients $(n=103)$

\begin{tabular}{|l|l|}
\hline Age median (min-max) & $42(18-87)$ \\
\hline Gender $\mathbf{n}(\%)$ & \\
\hline Male & $33(32 \%)$ \\
\hline Female & $70(68 \%)$ \\
\hline COHb level (\%) median (min-max) & $21.4(7.1-51.8)$ \\
\hline Presentation symptoms [n (\%)] & \\
\hline Headache & $80(78 \%)$ \\
\hline Nausea & $61(59 \%)$ \\
\hline Dizziness & $55(53.6 \%)$ \\
\hline Syncope & $13(12.3 \%)$ \\
\hline GCS score median (min-max) & $14.98(14-15)$ \\
\hline Hyperbaric oxygen therapy n (\%) & $19(17.9 \%)$ \\
\hline Lactate 1 median (min-max) & $2.9(0.3-9.3)$ \\
\hline Lactate 2 median (min-max) & $1.3(0.1-7.20)$ \\
\hline Lactate clearance median (min-max) & $0.33(-8.33-0.96)$ \\
\hline Troponin median (min-max) & $1.7(0.0-184.3)$ \\
\hline CoHb: carboxyhemoglobin, GCS: Glasgow Coma score, min: minimum, max: maximum
\end{tabular}

Table 2. Correlation coefficients between $\mathrm{COHb}$ levels and lactate-1, lactate clearances

\begin{tabular}{|l|l|l|}
\hline Variables & Correlation coefficient & $\mathbf{p}$ \\
\hline Lactate-1 & 0.490 & 0.000 \\
\hline Lactate clearance & 0.291 & 0.003 \\
\hline
\end{tabular}

$\mathrm{COHb}$ : carboxyhemoglobin 
lactate level was significantly higher in the HBOT group compared to the NBOT group $(p=0.039)$ (Table 3$)$.

A ROC analysis was performed, and the AUC was calculated to find out the cut-off level for the initial lactate level to predict the need for HBOT. The AUC value was found to be $0.708(0.567-0.850)(p=0.006)$ (Figure 1). Accordingly, when the cut-off value was taken $1.75 \mathrm{mmol}$, the sensitivity and specificity values of initial lactate were $77 \%$ and $56 \%$, respectively.

\section{Discussion}

In the present study, which we evaluated lactate and lactate clearance levels in CO intoxication, we found three important results. Firstly, we found a higher admission lactate level among patients with $\mathrm{CO}$ intoxication, which reflects tissue hypoxia occurring secondary to hypoperfusion in CO intoxication. Secondly, initial lactate levels were significantly higher in the HBOT group than the NBOT group. Clinicians need to subjectively evaluate injuries occurring secondarily to hypoxia for deciding to proceed with HBOT in CO intoxication. Our result suggests that lactate, a direct indicator of tissue hypoxia, maybe a suitable marker for use in decision making regarding the appropriate treatment modality before overt signs arise. Following this thought, we found that the AUC value of initial lactate in predicting the need for HBOT was 0.708 . Lastly, we found a greater lactate clearance in patients administered HBOT than those who were not. Therefore, we believe that, by reflecting the improvement occurring in tissue hypoxia, lactate clearance may be used to evaluate treatment response.

Table 3. Comparison of lactate-1, lactate-2 and lactate clearance levels according to treatment groups

\begin{tabular}{|l|l|l|l|}
\hline Variables & Received HBOT & Received NBOT & p \\
\hline Lactate-1 & $3.6(1-9.3)$ & $1.8(0.3-7.1)$ & 0.006 \\
\hline Lactate-2 & $1.2(0.6-3.4)$ & $1.3(0.1-5.2)$ & 0.514 \\
\hline Lactate clearance & $0.51(-0.25-0.80)$ & $0.27(-2.3-0.96)$ & 0.017 \\
\hline Lactate change & $51 \%(-25-80)$ & $33 \%(-66-95)$ & 0.039 \\
\hline HBOT: hyperbaric oxygen therapy, NBOT: normobaric oxygen therapy
\end{tabular}

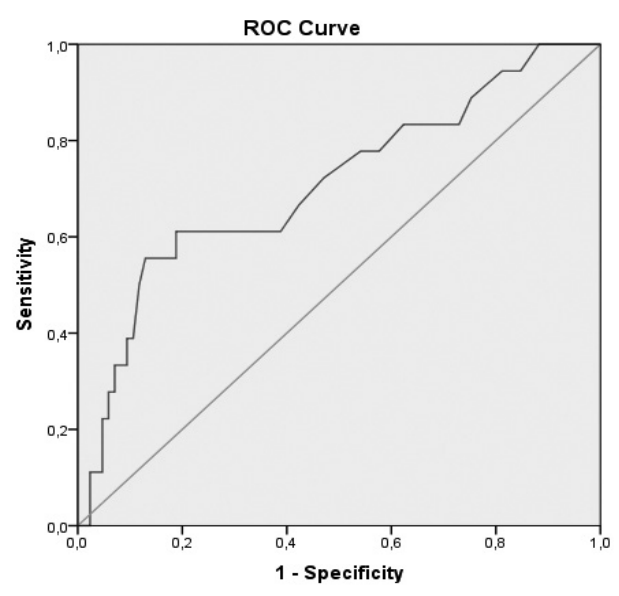

Figure 1. Receiver operating characteristic curve of the initial lactate to predict the need for hyperbaric oxygen therapy

ROC: receiver operating characteristic
The diagnosis of $\mathrm{CO}$ intoxication is classically made by an exposure history and $\mathrm{COHb}$ level (4). As $\mathrm{COHb}$ impairs oxygen-carrying capacity and tissue oxygen use independently of the oxygen amount, intoxicated patients may have normal oxygen saturation and partial oxygen pressure in arterial blood gas analysis. Furthermore, studies in the literature have underlined that the $\mathrm{COHb}$ level inadequately reflects intoxication-related acidosis and various complications, including delayed neurological sequelae $(5,12)$. For this reason, a rapid, reproducible, and effective marker is needed to monitor tissue hypoxia. By reflecting tissue hypoxia, which is the last step in the pathophysiology of many disease states, lactate has recently proved its value in a variety of disorders $(8,13)$. In CO intoxication, a significant correlation was reported between initial lactate and $\mathrm{COHb}$ levels by Moon et al. (12) $(r=0.493, p<0.001)$, Doğan et al. (9) $(r=0.738, p<0.001)$, Cervellin et al. (11) $(r=0.54, p<0.001)$ and Emektar et al. (10) $(r=0.588, p<0.001)$. We also found a moderately strong correlation between lactate and $\mathrm{COHb}(r=0.490 ; p<0.001)$. The differences of correlation strength between our study and the others in the literature may be due to the heterogeneity of disease severity among the study populations and differences between initial median $\mathrm{COHb}$ levels.

The most important decision made by the clinician regarding management is whether HBOT or only NBOT would be administered. Unfortunately, clear criteria regarding the use of HBOT in this indication have not yet to be defined. Subjective criteria widely used in clinical practice include end-organ injuries secondary to hypoxia (1). Thus, predicting hypoxia severity early in the course before ischemia occurs would bring the clinician one step forward in the disease management. As lactate starts to increase after the mitochondrial oxidative capacity is overwhelmed, it may warn the clinician about the severity of tissue hypoxia in advance of ischemic injury (14). Cervellin et al. (11) and Icme et al. (15) reported a more significant lactate increase among patients treated with HBOT. Doğan et al. (9) found higher lactate levels in patients with mental status changes and the need for HBOT compared to those without; they also reported an AUC level of 0.83 for plasma lactate levels in predicting HBOT need (9). In agreement with the literature, we found a higher admission plasma lactate level among patients that received HBOT and found an AUC value of 0.708 for predicting HBOT need. Based on this observation, we believe that higher lactate levels may warn clinicians about the severity of tissue hypoxia and the need for HBOT.

As it is a static parameter, it has been thought that a single lactate measurement is rather useful for risk prediction. As it indirectly reflects an improvement in tissue hypoxia, lactate clearance is thought to assume a more effective role in clinical monitorization (8). Many studies have reported the usefulness of lactate clearance for treatment monitoring and predicting prognosis in sepsis, severe sepsis, and septic shock $(7,16,17)$. Nevertheless, several studies have reported that its use is not limited to sepsis. Wada et al. (18) reported that a higher lactate clearance might be useful for differentiating patients without active bleeding among those with upper gastrointestinal bleeding. Odom et al. (19), in a large trauma series, found that lactate clearance was an independent predictor of mortality. Zhang's meta-analysis reported that lactate clearance is a useful biomarker for predicting mortality among critically ill patients (8). Slottosch et al. (20) underlined that lactate 
clearance measurement was more effective at rating treatment efficacy and determining prognosis than a single lactate measurement among patients undergoing extracorporeal membrane oxygenation. There is limited knowledge on the role of lactate clearance in intoxications. Liu et al. (21) reported that lactate clearance might be used for determining prognosis in acute paraquat intoxication. Emektar et al. (10), in the only study that, to our best knowledge, examined the relationship between treatment modalities and lactate clearance in $\mathrm{CO}$ intoxication, found a greater lactate clearance (64\%) in patients receiving HBOT than those receiving no such therapy (52\%), which they attributed to a more rapid lactate clearance depending on treatment type. We found a greater lactate clearance among patients receiving HBOT than those receiving NBOT. We think that this result is due to reduced lactate production secondary to a more effective reduction of tissue hypoxia by HBOT. Also, we think that, in this way, it is possible to evaluate the treatment efficiency by observing both inter-sessional lactate clearance among patients receiving HBOT and at certain time intervals among those receiving NBOT. Similarly, in cases that HBOT is not chosen as the therapy modality or NBOT is thought to be enough while making treatment decisions, inadequate lactate clearance may indicate an insufficient improvement in tissue hypoxia and guide clinicians toward HBOT. We, therefore, believe that lactate clearance may be used as a monitoring tool for treatment response in $\mathrm{CO}$ intoxication as in other critical diseases.

\section{Study Limitations}

Our study has some limitations. First of all, as this was a singlecenter study, our results are not generalizable to all centers. Secondly, erroneous data in the hospital records may have influenced the study results owing to its retrospective design. Additionally, neurological and cardiac involvement was not considered. As our hospital was not a hyperbaric center, cases admitted via ambulance were relatively milder CO intoxication cases than those who presented on an outpatient basis. Therefore, based on the assumption that our patient population may not have had adequate heterogeneity, we did not compare disease severity and lactate and lactate clearance. The above parameters were only compared with the need for HBOT. We think that this was one of the major limitations of our study.

\section{Conclusion}

In the present study, we determined that the initial lactate level and lactate clearance are rapidly performed and effective markers that may be used in the diagnostic and treatment processes of CO intoxication. We believe that particularly lactate clearance may provide valuable information in predicting the need for HBOT and assessing treatment efficacy as a monitorization marker.

Ethics Committee Approval: A local ethics committee approval (Ankara Keçiören Training and Research Hospital Ethics Committee, decision no: 2012-KAEK-15/1674, date: 23.05.2018).

Informed Consent: Retrospective study.

Peer-review: Externally peer-reviewed.
Authorship Contributions: Concept - S.D., E.E., H.U., Ö.Ö., Y.C..; Design - S.D., E.E., H.U., S.K.C.., Ö.Ö.; Data Collection or Processing - H.U., S.K.Ç., Ö.Ö., Y.Ç.; Analysis or Interpretation - S.D., E.E., S..K.Ç., Y.C..; Literature Search - S.D., H.U., S.K.C., Ö.Ö., Y.Ç.; Writing: S.D., E.E.

Conflict of Interest: No conflict of interest was declared by the authors.

Financial Disclosure: The authors declared that this study received no financial support.

\section{References}

1. Chiew AL, Buckley NA. Carbon monoxide poisoning in the 21st century. Crit Care 2014; 18: 221.

2. Hampson NB. U.S. Mortality Due to Carbon Monoxide Poisoning, 1999-2014. Accidental and Intentional Deaths. Ann Am Thorac Soc 2016; 13: 1768-74.

3. Weaver LK. Clinical practice Carbon monoxide poisoning. N Engl J Med 2009; 360: $1217-25$.

4. Hampson NB, Piantadosi CA, Thom SR, Weaver LK. Practice recommendations in the diagnosis, management, and prevention of carbon monoxide poisoning. Am J Respir Crit Care Med 2012; 186: 1095-101.

5. Hampson NB, Hauff NM. Carboxyhemoglobin levels in carbon monoxide poisoning: do they correlate with the clinical picture? Am J Emerg Med 2008; 26: 665-9.

6. Saugel B, Trepte CJ, Heckel K, Wagner JY, Reuter DA. Hemodynamic management of septic shock: is it time for "individualized goal-directed hemodynamic therapy" and for specifically targeting the microcirculation? Shock 2015; 43: 522-9

7. Nguyen HB, Rivers EP, Knoblich BP, Jacobsen G, Muzzin A, Ressler JA, et al. Early lactate clearance is associated with improved outcome in severe sepsis and septic shock. Crit Care Med 2004; 32: 1637-42.

8. Zhang Z, Xu X. Lactate clearance is a useful biomarker for the prediction of all-cause mortality in critically ill patients: a systematic review and metaanalysis. Crit Care Med 2014; 42: 2118-25.

9. Doğan NÖ, Savrun A, Levent S, Günaydın GP, Çelik GK, Akküçük H, et al. Can initial lactate levels predict the severity of unintentional carbon monoxide poisoning? Hum Exp Toxicol 2015; 34: 324-9.

10. Emektar E, Ramadan H, Yüzbaşıoğlu Y, Vural S, Coșkun F. Use of lactate clearance in determining serum lactate levels and effectiveness of treatment in carbon monoxide poisonings. KÜ Tıp Fak Derg 2017; 19: 60-5.

11. Cervellin G, Comelli I, Rastelli G, Picanza A, Lippi G. Initial blood lactate correlates with carboxyhemoglobin and clinical severity in carbon monoxide poisoned patients. Clin Biochem 2014; 47: 298-301.

12. Moon JM, Shin MH, Chun BJ. The value of initial lactate in patients with carbon monoxide intoxication: in the emergency department. Hum Exp Toxicol 2011; 30: 836-43.

13. Revelly JP, Tappy L, Martinez A, Bollmann M, Cayeux MC, Berger MM, et al. Lactate and glucose metabolism in severe sepsis and cardiogenic shock. Crit Care Med 2005; 33: 2235-40.

14. Haas SA, Lange T, Saugel B, Petzoldt M, Fuhrmann V, Metschke M, et al. Severe hyperlactatemia, lactate clearance and mortality in unselected critically ill patients. Intensive Care Med 2016; 42: 202-10.

15. Icme F, Kozaci N, Ay MO, Avci A, Gumusay U, Yilmaz M, et al. The relationship between blood lactate, carboxy-hemoglobin and clinical status in CO poisoning. Eur Rev Med Pharmacol Sci 2014; 18: 393-7. 
16. Ryoo SM, Lee J, Lee YS, Lee JH, Lim KS, Huh JW, et al. Lactate Level Versus Lactate Clearance for Predicting Mortality in Patients With Septic Shock Defined by Sepsis-3. Crit Care Med 2018; 46: 489-95.

17. Bolvardi E, Malmir J, Reihani H, Hashemian AM, Bahramian M, Khademhosseini $\mathrm{P}$, et al. The role of lactate clearance as a predictor of organ dysfunction and mortality in paitents with severe sepsis. Mater Sociomed 2016; 28: 57-60.

18. Wada T, Hagiwara A, Uemura T, Yahagi N, Kimura A. Early lactate clearance for predicting active bleeding in critically ill patients with acute upper gastrointestinal bleeding: a retrospective study. Intern Emerg Med 2016; 11: 737-43.
19. Odom SR, Howell MD, Silva GS, Nielsen VM, Gupta A, Shapiro NI, et al. Lactate clearance as a predictor of mortality in trauma patients. J Trauma Acute Care Surg 2013; 74: 999-1004.

20. Slottosch I, Liakopoulos O, Kuhn E, Scherner M, Deppe AC, Sabashnikov A, et al. Lactate and lactate clearance as valuable tool to evaluate ECMO therapy in cardiogenic shock. J Crit Care 2017; 42: 35-41.

21. Liu XW, Ma T, Qu B, Ji Y, Liu Z. Prognostic value of initial arterial lactate level and lactate metabolic clearance rate in patients with acute paraquat poisoning. Am J Emerg Med 2013; 31: 1230-5. 